М. Пазяка. - К. : Либідь, 2004. - 352 с. - («Пам’ятки історичної думки України»).

7. Философский словарь / Под ред. И. Т. Фролова. - [4-е изд.]. - М. : Политиздат, 1980. - 444 с.

УДК $811.161 .2 ' 282.3(477.82)$

3. С. Мацюк

\title{
«ДІВКА БЕЗ КОСИ ЯК КІНЬ БЕЗ ГРИВИ» (НА МАТЕРІАЛІ ЗАХІДНОПОЛІСЬКОЇ ФРАЗЕОЛОГІї)
}

Мацюк 3. С. «Дівка без коси як кінь без гриви» (на матеріалі західнополіської фразеологі).

У статті проаналізовано фразеологічні одиниці Західного Полісся, які характеризують зовнішній вигляд жінки та чоловіка, зокрема фраземи на позначення волосся. Простежено спільні та відмінні риси жінок і чоловіків в ареальному просторі досліджуваного регіону, що стосуються фразеосемантичного ряду «Волосся».

Ключові слова: опозиція, чоловік, жінка, фразема, Західне Полісся.

Мацюк 3. С. «Девушка без косы как конь без гривы» (на материале захиднополесской фразеологии).

В статье проанализированы фразеологичные единицы Западного Полесья, которые характеризуют внешний вид женщины и мужчины, в частности их волосы. Прослежены общие и отличные черты женщин и мужчин в ареальном пространстве исследуемого региона, что касаются фразеосемантичного ряда «Волосы».

Ключевые слова: оппозиция, мужчина, женщина, фразема, Западное Полесье.

Matsyuk Z. S. «A girl without tress as a horse without a mane» (on material of Western Polessia phraseological units).

Phraseological units of Western Polissya, which characterize original appearance of «woman» and «man», are analysed in the article, in particular hairs. The general and distinctive features of women and men are traced in areal space of the explored region, that means the phraseosemantic row of «Hairs».

Key words: opposition, man, woman, frazema, Western Polessia.

В останні два десятиріччя відбулося не лише переосмислення проблеми взаємовідношення статей, а й співвідношення статей, що викликає посилений інтерес до «гендерної фразеології» [11, с. 165], або ж «фразеологічної гендерології» [11, с. 165], яка відкриває нові теоретичні й 
пізнавальні перспективи. У центрі уваги гендерної лінгвістики як одного 3 напрямів гендерології - фактично будь-яка сфера мовознавства (проблеми референції, граматики, лексикології і фразеології, семантики і прагматики тощо) з погляду відображення в ній гендерних відношень. Дослідження гендеру у філології проводиться на різних рівнях, зокрема на рівні ставлення до жінок та чоловіків. Значення «категорії статі» [11, с. 3], очевидне, коли розглядають категорії фемінності та маскулінності в їх безпосередньому зв'язку із життям жінок і чоловіків.

У лінгвістиці існує протиставлення базових компонентів людської культури «чоловік - жінка» як онтологічної опозиції, яка лежить в основі мови. Характеризуючи людину, представника чоловічої чи жіночої групи, як базову структуру соціальної належності, найбільш значущим є те, як вона сама себе гендерно ідентифікує. Аналогічно опозиція «чоловік» «жінка» грунтована на вираженні маскулінних чи фемінінних рис, оскільки вона виражає статусно-рольову диференціацію людей. Жінки та чоловіки по-різному розвинені i біологічно, i культурно, мають різну самосвідомість, різні соціальні та духовні цінності, відмінні роздуми щодо світу.

Не менш важливою виступає статева стратифікація, яка визначає соціальні (у тому числі ритуальні) й економічні статеві ролі, відмінність у поведінці чоловіків і жінок, уявлення про чоловіче та жіноче начала в культурі, регулює норми поведінки, обряди, що чітко простежено й у фразеологічній системі Західного Полісся.

Метою нашого дослідження поставлено проаналізувати та провести паралелі фразеосемантичних рядів «Дівоча коса» $\leftrightarrow$ «Неголений i непідстрижений чоловік», «Рідке волосся у жінок» $\leftrightarrow$ «Лисий чоловік».

Фразеологія української мови містить багатий історичний матеріал про наш народ, його звичаї, ідеали, мрії та сподівання. Вивчати фразеосистему неможливо без залучення всіх фразем, які побутують в окремих ареалах. Споконвіків людина особливого значення надавала своєму волоссю. Уважалося, що волосся зберігає інформацію про рід, тобто приховує в собі родову пам'ять, відіграє роль своєрідного медіатора між Небом і Землею. За його фактурою можна визначити характер людини. У народних уявленнях у ньому «вмістилище людських сил» [2, с. 92]. Для українського народу волосся завжди відігравало важливу роль, особливо акуратно заплетена дівоча коса наділена багатою символікою.

Коса - це не лише символ дівочої краси та вроди, а й ознака статусу дівчини. Це ще й вияв чистоти, незайманості. Пошанування чи осуд поведінки дівчини колись був виражений через ставлення до іiі коси шляхом чинення тих чи тих дій - возвеличення, пошанування або ж осуду, зневаги. Цей вид жіночої зачіски наділений шлюбною символікою: одну косу носили дівчата (у тому числі й ті, що не вийшли заміж), дві коси - 
заміжні жінки [6, II, с. 615]. Перше заплітання коси означало іiі перехід у нову вікову категорію. Допоки ій підстригали волосся, вона була «дівчинкою», а як тільки заплітали косу - ставала «дівкою», тобто дівчиною на виданні [6, II, с. 615]. Народ розглядав дівочу косу як свідчення відтворювальної сили, напр.: д'і́вка без коси́ йак к'iн' без гри́ви (Клб). Відповідно до віку змінювалася і зачіска дівчини: коли дівчина «заручиться», то вона опускає косу (Чорногорія), викладає іï кругом голови (Поморав'є), або ж вплітає в косу стрічку і под.

Довга коса - предмет гордості й особистої охайності дівчини. Позитивну оцінку дівчина отримує через такі номінації коси за розміром: косá до пойáca (Брд, Гбн, Дтн), рýca кóca do пойáca (Душ, Слв), зам’imáŭe косо́йу (Псн), мете́ косо́й (Брз, Овд), коса́ йак в руса́лки «про розкішне волосся, заплетене в косу» (Звн). Водночас народ помічає відхилення від ідеалу, яке виявлено у формі, розмірі та чепурності коси: коса́ йак прач [прач - дерев'яне пристосування для прання білизни] «товста розтріпана коса» (Жрч, Крп, СтЗг, Яснв), коса́ йак м’iтла́ (Млн), хв ’icm йак в коби́ли (Кзл, Пвр) || коса́ йак в коби́ли хв 'icm (Тпл) || кон'а́чий хв 'icm (Змш), коса́ йак у кон'á хвист (Влх), уй коро́тка куса́ йак ми́шачий хвист (Ббр), ми́шачий хво́стик (Кзл, Ств), коса́ йак конопл'á «тонка розтріпана коса» (Змш), косá йaк zapána [гapána - довгий батіг] «про тонку довгу косу» (Мшс), які мають негативний семантичний відтінок.

У багатьох міфопоетичних системах волосся символізувало радість життя, духовний розвиток, плодючість. Водночас коса символізувала чарівну дівочу вроду: коса́ - ж’іно́ча краса́ \| коса́ - d'іво́ча краса́ (Клб). Також колись коса була своєрідною суспільно-моральною ознакою чепурності, охайності дівчини [7, с. 128]. Уставши вранці, вона мусила передусім розчесати й заплести косу, тому через такий конкретизатор робився висновок, напр.: коса́ йак прач - д'івка йак срач [5, с. 13].

Здавна відомий весільний обряд розплітання та розчісування коси молодої перед вінцем на ознаку ії дівочої чистоти. Якщо дівчина втрачала дівочу честь до шлюбу, іiі косу відрізали, і це була велика ганьба, а якщо народила позашлюбну дитину, то не мала більше права ходити 3 непокритою головою [4, с. 309]. Насильне обстригання волосся символізувало неславу за втрату вінка, тобто цнотливості. Таку дівчину називали стрига. Це пов'язано з тим, що коса була символом незайманості, святості [7, c. 51]. Саме в осередку молоді найраніше дізнавалися про втрату цноти дівчиною. Про це повідомляли батькам символічними діями: вимазували паркан дьогтем, гноєм; знімали ворота та ін. [8, с. 216].

У давнину на Русі-Україні категорично заборонялося заміжній жінці «світити волоссям» [4, с. 23], тому голову покривали хусткою чи наміткою: завйаза́ла ху́стку (Яснв) || хусти́ну над'і́ла (Бтн) || вд'агну́ла ху́стку «вийти заміж» (РБрс). Оскільки непокрита дівоча коса символізувала цнотливість, то неодмінним складником весільного ритуалу 
було покривання молодої. Наречена схилялась обличчям до хліба, а свахи тричі колихали над їі головою натягненою на чотири кути хусткою. Це був кульмінаційний момент усього дійства - зробили 3 дівки молодицю. Відтепер вона повинна обов'язково завиватися покривом [8, с. 83], адже дівчина переходить під владу чоловіка, який заволодів ії косою, а отже й честю. Тому з'явитися перед чужими без хустини означало зрадити своєму чоловікові [7, с. 51].

У фразеологізмах обр'і́зали косу́ (Гбн, Дбрв, Дгш, Крп, Овд, Снв) одр'і́зати косу́ (Дбр) \|| косу́ обр'і́зала (Пвр) задокументований інший давній звичай, поширений до тридцятих років XX ст. на КаміньКаширщині, - молодій утинали косу.

Водночас волосся в чоловіків постає уособленням чоловічої сили та гідності: «біблійний Самсон утратив свою силу через те, що Даліла відрізала йому волосся. Ця біблійна легенда знайшла втілення в символіці народного епосу та в народних звичаях (спочатку носили довге волосся, адже воно пов'язувалося 3 долею; потім, коли усталився звичай стригти волосся, хоронили його від небезпеки, зазвичай спалювали)» [4, с. 111]. Волосся - у народних уявленнях осереддя життєвих сил людини. Словенці вірили, що з волоссям і бородою можна забрати в чоловіка силу і здоров'я $[6,2$, с. 420]. Люди приклонялися перед землею, вважаючи сушу тілом, каміння - кістками, воду - кров'ю, а рослини - волоссям велетенської істоти. Отже, у казках волосся - символ енергії, плодючості, буйної рослинності. На Русі-Україні лише воїни «повністю голили волосся, присвячуючи своє життя і життєву силу Перуну» [7, с. 51]. Візантійців дуже вразила зачіска князя Святослава - на виголеній голові був лише жмут волосся на маківці (подібний до запорозького «оселедця»).

У народнорозмовній фразеології представлено одиниці, дошкульні за своєю прагматикою та стилістичним забарвленням. На запитання «Як говорять про неголеного i непідстриженого чоловіка? Із чим його порівнюють?» зафіксовано фраземи, у яких проведено паралелі: iз тваринами; демонічними образами; особами, які займають відповідний сан; відомими персонажами; неохайними особами, наприклад: йак иииган (Гв), йак маз'а́p «маляр» (Звн), йак турм'іŭáн [людина, яка перебуває в місцях позбавлення волі] (Мшв), запусти́в себе́ йак та нер'áха (Чрк), йак кучкуда́н (ВВл, Остр) та за асоціативними порівняннями: зар'і́с йак л'іс (Дтн), заро́слий йак чума́ (Брд), шч ’iтка на мо́рд'i ви́росла (Пст), зар'і́ йак ку́чма (Гбн), йак страши́дло (Хрп).

Волосся - багатозначний символ. Воно символізувало ірраціональні космічні сили та біологічні інстинкти. Добровільне постригання, наприклад, у ченці, означало відмову від усіх земних утіх, абсолютний аскетизм [7, с. 50], тому після постригання священнослужителі мали довге волосся, великі бороди, що відображено у фразеології Західного Полісся, 
наприклад: йак мана́x (Бхв), йак ста́реu (Крч), зар'і́ йак ба́m'ушка (Хлп) ॥ обро́с би пип (Бр).

Один із найпопулярніших персонажів української демонології чорт, що уособлює ворожі людині сили. Він виступає одночасно зооморфною й антропоморфною істотою, характерні прикмети якої довгий ніс, палаючі очі, густе чорне волосся, наприклад: заро́слий йек чорт (Врк) || заро́слий йак чорт [боло́т'аний] (ВВлн, Клн) || лахма́тий йак чорт (ВВл, Остр), зар'і́с йак вовкула́ка (Шкл).

Фраземи 3 власними назвами властиві для мовців говірок населених пунктів, напр., вираз зар'і́с йак Л'у́бей'ке о́зеро (Зрч). Такі одиниці територіально вмотивовані: чоловіка порівнюють із зарослим озером, яке розташоване неподалік. Також виявлено порівняння 3 відомими кіногероями чи історичними особами, як-от: йак d'id Моро́з (Трг), вулуха́тий йак Будула́й (Гбн, Крп, Яснв) \| обро́ший йак Будула́й (Тпл) \| зар'і́с йак Будула́й (Слв) || обр'і́ йак Будула́й (Пвр) \| Будула́й патла́тий (Хрп), хо́дит' йак бомж (Брд) \| запу́стивс'а йак бомж (Ярс) \| йак бомжа́ка (Бтн), йак Фе́дел' Ка́стро (Мшв).

Часто образними конкретизаторами виступають тварини, які створюють негативну конотацію: заро́слий йак вовк (Дбр) || зар'і́с йак вовк (Пст), зар'і́с йак дз'ік (СтЗг) || заро́слий йак дз'ік [дз'ік - дикий кабан] (Млт), обри́с йак ведм 'íd' (Брв) || заро́слий йак медв 'ід' (Лпн) || йак ведме́д' (МГл), патла́тий йак пес (Смд), зар'і́ йак ма́впа (Млн, Яснв). Паралельно в західнополіській фразеології вживані фраземи із позитивною конотацією на позначення красивого волосся: кучера́вий чуб, то саме́ хороство́ (Лкч).

Рідке волосся в дівчат та жінок представлене не меншою кількістю фразеологічних одиниць. Густа шевелюра символізує життєвий порив, радість життя, духовний розвиток [7, с. 50]. Імовірно, у патріархальному суспільстві побутувало вірування, що у волоссі жінки як представниці чужого роду містяться сили, що вороже сприймають покровителі та опікуни роду, у який вона прийшла, зокрема й природи, через що не сприяють урожайності, спричиняють різні катаклізми тощо, тому ці фраземи мають негативну оцінку. Як відповідь на запитання «Як говорять про рідке волосся у жінок?» зафіксовано такі сполуки на позначення рідкого волосся: $\partial \varepsilon^{\prime} i$ волоси́нки торчи́m' (Дтн), воло́с':a йак понаса́жене (Снв) \| воло́с':a йак поса́жене (Дбр) та розтріпаного тонкого волосся: воло́с': а йак n'і́рйа (Жрч) \| ма́ло n’íрйа на голов 'í (Пст), воло́с': а йак пачо́си «про рідке розтріпане волосся» (Вдр), конопл'а́не воло́с':a «тонке рідке волосся» (Тпл), воло́с':a йак стр'іхха «розтріпане волосся» (Слв) || гулува́ йак стр'і́ха (Рсв), на гулув’í йак на купи́и'i (Клк), йак ба́ба йагá (Гдм), обску́бана ку́рка (Яснв), йак n’iдти́кана (Псн), йак ришипе́йда «про неакуратно зачесану» (Ткт).

Частотним у дослідженій фразеології є числівник три, який позначає малу кількість: три волоси́нки на голов 'i (Пвр) $\|$ три волоси́ни в три р'ади́ (Бтн) \| три волоси́ни в ш'і́ст' p'аd'і́ (Смд), три волоси́ни і т'і розпа́тлан'i (РБрс). 
У фразеологічних одиницях відбувається розмежування не лише за семантикою, а й за оцінкою. Негативної оцінки надають вербальні маркери: мітла, прач і под.

Із волоссям пов'язані особливі звичаї та повір'я. В українців відразу ж після народження дитини баба-повитуха відрізала у неї три пучки волосся, щоб у похилому віці не було лисини. На Західному Поліссі не меншу увагу приділяють чоловікам, які втратили волосся, що в широкому спектрі представлено у фразеології досліджуваного регіону. Предмети, які мають гладку поверхню, у західнополіській фраземіці виступають образним еквівалентом поняття чоловічої лисини: ли́сий йак йайџе́ (Бхв, Крч), ли́сий йак бу́блик (Рсв), йак ди́н'а (Ощв), йак гарбу́з (Трг), ли́сий йак колобо́к (Бтн), голова́ йак ша́рик (ВВл, Остр), ли́сий йак бубун (Ббр, Хлп) ॥ ли́сий йак бубен (Тпл, Яснв) || ли́сий йак бубон (Дтн, Псн) || ле́сий бу́бон (СтЗг) || ли́сий бу́бен (Ввн), го́лий йак буббен (Зтр), ли́са бу́ба (Гв), ли́сий йак Ле́н'ін (Ярс), йак зек (Хлп), на гулов’і йак на стол'і́- гла́дко (Клн), хоч шчи́гл'i бий (Хлп), йак са́лом пома́заний (Пвр) || йак са́лом пума́заний (Кзл), ли́са башка́ (Змш), на пога́ному по́л'i й трава́ не росте́ (Крп).

Місяць і сонце символізують чоловіче та жіноче начала. У різних міфологіях їм притаманні різні ролі. У фразеологічних одиницях цього фразеоряду простежено паралелі лисини чоловіка із місяцем та сонцем, які засліплюють очі, напр.: засв 'іти́в м'іс'аи' (Брз) || ли́сий йак м'іс'ай (Смд), блишчи́m' ли́сина йак со́нечко (Дкв) \| св'ітии'а йак со́нще (Псн) || со́нечко зас'а́йало (СтЗг) || со́нечко засв'іти́ло (Слв) || вноч'і́ бу́де св'іти́ти со́нечко (Звн), що надає сполукам позитивної оцінки.

Фразеологічним одиницям зі значенням «лисий» властиві такі порівняння: 1) із хатнім начинням: ли́сий йак маког'їн (Гбн), ход'а́ча мак'ímpa (Дбр) \|| ли́са мак'ímра (Пст, Смл), ли́сий йак товка́ч (Дбрв, Овд, Снв, Зрч, Лбш, Прп) \|| голо́ва йак товка́ч (Брз), ли́сий йак герияома́x [гериома́x - товкач] (ВВл), ли́сий йак пате́л'н'а (Вгщ); 2) із частиною дерева: ли́сий йак пол'іно (Лбш); 3) із частинами тіла: ли́сий йак ду́na (Мшв), гулува́ йак кул'іно (НРд) || ли́сий йак кол'іно (Брс, Гдм, Дбр, Жрч, Мшв, Слв, РБрс) || ли́сий йак кул'і́но (Бн), го́ла голова́ йак кул'іно́ (Млт) ॥ ле́сий йек кул'іно (Врк) || го́лий йак кол'іно (Лбн); 4) із предметами, які світяться, віддзеркалюють: с'в 'і́тла пол'а́на (Яснв), с'в'ітии'а йак бл'а́ха (Млн), ли́сий би лихта́р (Бр), ли́сий аж блишчи́т' (Бхв), ли́сий йак зе́ркало (Ярс) \|| лиссий йак дзе́ркало (Клч) || йак дзе́ркало (Жрч), св 'ітит' ли́синойу йак л'у́стром (Тпл) та ін.

Більшість фразем переважно породжені конотативною модальністю 3 негативною ознакою, чому сприяють назви таких тварин: баран, и̧ап, наприклад: ли́сий йак бара́н (Хрп) || ли́сина йак в барана́ (Бржк), ли́сий йак u̧an (Бтн). Багато фразем цього ряду римована: ли́сий бу́бен (впав із ду́бу) (Клб), ли́са бу́ба впа́ла з ду́ба (ВВл, Остр). 
Структуровий елемент лисий накладає відбиток негативного поцінування через відстеження асоціативних зв'язків із чортом, бісом. Стереотипне уявлення про цю істоту «як волохату, укриту хутром, не власне слов'янське, язичницьке, а запозичене 3 європейської церковної традиції. Давньоруські ж мініатюри подають чорта як зазвичай людиноподібну істоту 3 витягнутою головою та часто лису, із «не причесаними» крилами за спиною, куцим хвостом та гусячими п'ятами» [9, с. 496-500]. На досліджуваній території зафіксовано поодинокі приклади фразеологічних одиниць із компонентом лисий на позначення розумного чоловіка, напр.: ли́сий, бо розу́мний, проте хи́трий, но ни ли́сий [1].

У західнополіських фразеологічних одиницях сконцентровано значний обсяг культурної інформації міфологічного, філософського, релігійного, фольклорного характеру та викладено світоглядні концепти. Фразеологізми в межах опозиції «чоловіче» - «жіноче» проаналізовано відповідно до вираженння маскулінних або ж фемінних ознак, що відображено у фраземах на позначення «дівоча / жіноча коса», «неголений і непідстрижений чоловік», «рідке волосся у жінок», «лисий чоловік». У досліджених фразеологічних одиницях чітко простежена опозиція «густе довге» та «рідке тонке» волосся, проте для позначення густого волосся фразем уживано менше.

Ббр - Бобрин Млинів Рвн

Бн - Буяни Луцьк Влн

Бр - Бір Зарічн Рвн

Брв - Борове Заріч Рвн

Брд - Броди Ратнів Влн

Бржк - Бережки Дубров Рвн

Брз - Березичі Любешів Влн

Брс - Береськ Рожищ Влн

Бтн - Ботин Луцьк Влн

Бхв - Бихів Любешів Влн

ВВл - Володимир Волинський Влн

Ввн - Вовничі Млинів Влн

Вгщ - Воєгоща К-Кашир Влн

Вдр - Видранка Старовиж Влн

Влх - Вільхівка Горохів Влн

Врк - Ворокомне К-Кашир Влн

Гбн - Губин Горохів Влн

Гв - Гайове Ківерц Влн

Гдм - Годомичі Маневиц Влн

Грн - Гірники Ратнів Влн

Дбр - Добре К-КаширВлн

Дбрв - Діброва Володимирец Рвн

Дгш - Довгошиї Млинів Рвн

\section{Список населених пунктів}

Дкв - Диковини Горохів Влн

Дтн - Датинь Ратнів Влн

Жрч - Жиричі Ратнів Влн

Звн - Звиняче Горохів Влн

Змш - Замчани Ратнів Влн

Зрч - Заріччя Ковел Влн

Зтр - Затурці Локач Влн

Кзл - Козлиничі Ковел Влн

Клб - Клубочин Ківерців Влн

Клк - Колки Маневиц Влн

Клн - Калинівка Маневиц Влн

Клч - Кульчин Турійськ Влн

Крп - Карпилівка К-КаширВлн

Крч - Кричильськ Сарнен Рвн

Лбн - Лобна Любешів Влн

Лбш - Любешів Влн

Лкч - Локачі Влн

Лпн - Липне Ківерц Влн

Остр - Острівок В-Волин Влн

Ощв - Ощів Горохів Влн

Пвр - Поворськ Ковел Влн

Прп - Прип’ять Шацьк Влн

Псн - Посників Млинів Рвн

Пст - Постійне Костопіл Рвн

РБрс - Р.-Берестечко Демидів Рвн

Рсв - Русів В-Волин Влн

Слв - Словатичі Ківерц Влн

Смд - Смідин Старовиж Влн

Смл - Смолярі Старовиж Влн

Снв - Синове Старовиж Влн

Ств - СтавокКіверц Влн

СтЗг - Старий Загорів Локач Влн

Ткт - Тойкут Ковел Влн

Тпл - Топільне Рожищ Влн

Трг - Торговиця Млинів Рвн

Хлп - Холопичі Локач Влн

МГл - Мала Глуша Любешів Влн Хрп - Хрипськ Шацьк Влн

Млн - Мельники Старовиж Влн Чрк - Чаруків Луцьк Влн

Мшв - Машів Любомл Влн Шкл - Шклинь Горохів Влн

НРд - Нова Руда Маневиц Влн

Овд - Овадно В-Волин Влн Яснв - Ясенівка Рожищен Влн

\section{Література}

1. Аркушин Г. Л. Сказав, як два зв'язав / Г. Л. Аркушин. - Люблін ; Луцьк, 2003. - 178 с.

2. Войтович В. М. Українська міфологія / В. М. Войтович. - [2-е вид., стер.]. - К.: Либідь, 2005. - 662 с.

3. Громик Ю. В. Фразеологізми поліської говірки села Липно Ківецівського району Волинської області / Ю. В. Громик // Волинь- Житомирщина : іст.-філол. зб. з регіон. проблем. - Житомир : [б. в.], 2002. - № 8. - C. 152-170. 
4. Жайворонок В. В. Знаки української етнокультури : словник-довідник / В. В. Жайворонок. - К. : Довіра, 2006. - 703 с.

5. Мацюк 3. С. Із народу не викинеш : діалектний словник фразеологізмів / 3. С. Мацюк. - Луцьк : РВВ «Вежа» Волин. держ. ун-ту ім. Лесі Українки, 2006. - 134, [2] с.

6. Славянские древности : этнолингвистический словарь : в 5-и т. / [под ред. Н. И. Толстого]. - Т. 1. М. : Междунар. отношения, 1995 ; Т. 2.- М. : Междунар. отношения, 1999 ; Т. 3.- М. : Междунар. отношения, 2004. ; Т. 4. - М. : Междунар. отношения, 2009. - 656 с.

7. Словник символів культури України / [за заг. ред. В. П. Коцура]. - К. : Міленіум, 2002. - 260 с.

8. Українська етнологія : [навч. посіб.] / [за ред. В. К. Борисенко]. - К. : Либідь, 2007. - 400 с.

9. Яковлєва В. В. Фразеологізми 3 компонентом батько в контексті етнокультурних концептів / В. В. Яковлєва // Вісн. Прикарп. нац. ун-ту ім. В. Стефаника : Філологія. - 2007. - Вип. XV-XVIII. C. $496-500$.

10. Эмирова А. М. Оппозиция «мужчина - женщина» в русской фразеологии / А. М. Эмирова // Грани слова : сб. науч. ст. к 65-летию проф. В. М. Мокиенко. - М. : ООО «Изд-во ЭЛИПС», 2005. C. $165-169$.

11. Korsmeyer C. Gender w estetyce. Wprowadzenie / C. Korsmeyer / [przeklad Anna Ncher] / [redakcją naukową K. Wilkoszewska]. - Kraków, 2004. - S. 1-13.

\section{О. Г. Межов}

\section{МІНІМАЛЬНА СЕМАНТИКО-СИНТАКСИЧНА ОДИНИЦЯ У ФУНКЦІї АДРЕСАТА}

Межов О. Г. Мінімальна семантико-синтаксична одиниця у функції адресата.

У статті проведено системне дослідження адресатних синтаксем сучасної української літературної мови на матеріалі різностильових текстів у зв'язку з семантичними і валентними типами предикатів. Описано семантичні та морфологічні варіанти категорії адресатності в елементарних та неелементарних простих реченнях, її лексичне наповнення. Визначено способи ускладнення адресатної семантики іншими значеннями.

Ключові слова: мінімальна семантико-синтаксична одиниця, синтаксема, адресатна синтаксема, предикат, давальний відмінок.

Межов А. Г. Минимальная семантико-синтаксическая единица в функции адресата.

В статье проведено системное исследование адресатных синтаксем современного украинского литературного языка на материале разностилевых текстов в связи с семантическими и валентными типами предикатов. Описаны семантические и морфологические варианты категории адресата в элементарных и неэлементарных простых предложениях, ее лексическое наполнение. Определены способы осложнения адресатной семантики другими значениями.

Ключевые слова: минимальная семантико-синтаксическая единица, синтаксема, адресатная синтаксема, предикат, дательный падеж.

Mezhov A. G. Minimal semantic-syntactical unit in the function of addressee.

In the article system research of addressee sintaxem modern literary Ukrainian is conducted on material of texts of different styles in connection with the semantic and valency types of predicates. The semantic variants of category of addressee are described in the elementary and unelementary simple sentences, its lexical filling. The methods of complication of addressee semantics are definited by other values.

Key words: minimal semantic-syntactical unit, sintaxema, addressee, predicate, dativ.

У сучасному українському мовознавстві набуває поширення вчення про три синтаксичні одиниці: речення, словосполучення й мінімальну синтаксичну одиницю. Речення i словосполучення $є$ синтаксичними одиницями-конструкціями, а мінімальна синтаксична одиниця функціонує як їхній компонент. Функціональний багатоаспектний аналіз мінімальних 